\title{
Journal Evaluation Systems: Evolution and Practices in China's Social Sciences
}

\author{
Ying HUANG ${ }^{1,2,3}$, Ruinan $\mathrm{LI}^{1,2}$, Xiaoting LIU ${ }^{1,2}$, Lin ZHANG ${ }^{1,2,3 *}$ \\ ${ }^{1}$ School of Information Management, Wuhan University, China \\ ${ }^{2}$ Center for Science, Technology \& Education Assessment (CSTEA), Wuhan University \\ ${ }^{3}$ Centre for R\&D Monitoring (ECOOM) and Department of MSI, KU Leuven, Belgium
}

\begin{abstract}
Journal evaluation systems play an important role in academic evaluation. With many papers published in high-ranking journals, one can expect greater success in grant applications, higher internal resource allocations, faster promotions, and access to many other trappings of academic life. The expansion of China's research and development systems and its rise as a significant contributor to global innovation have seen journal evaluation become a significant and muchscrutinized issue. Thus, in this chapter, we offer a comprehensive analysis of the current stateof-the-art in journal evaluation systems and practices. The review begins with a history of social science journal evaluation in China. We then systematically compare the two most influential journal lists of the present day: the Chinese Social Sciences Citation Index (CSSCI) and the "Attraction, Management and Influence" Comprehensive Evaluation Report (AMI). A small selection of influential lists produced by universities, research institutions, and professional associations are also discussed. The material presented provides deep insights into how social sciences research in China is assessed. These findings may also reveal some information about the journal evaluation activities of other countries. Overall, our aim is to make a valuable contribution to the theory and practice of journal evaluation so as to promote the sustainable and healthy development of journal management and evaluation systems both in China and abroad.
\end{abstract}

Keywords: social sciences; journal evaluation; peer review; bibliometrics

(Note that hereafter, journal evaluation refers to journal evaluation for the social sciences unless otherwise specified.)

\footnotetext{
Ying HAUNG; ORCID: 0000-0003-0115-4581; Email: ying.huang@kuleuven.be Ruinan LI; ORCID: 0000-0003-2177-8076; Email: liruinan@whu.edu.cn Xiaoting LIU; ORCID: 0000-0003-4638-6941; E-mail: liu_xiaoting@whu.edu.cn Lin ZHANG; ORCID: 0000-0003-0526-9677; E-mail: linzhang1117@whu.edu.cn, Corresponding Author
} 


\section{History of Chinese journal evaluation in social sciences}

Theories of journal evaluation in China originated from the Western theories and practices of the 1960s when Qiyu Zhang and Enguang Wang introduced Chinese readers to the Science Citation Index (SCI) in 1964 (Zhang, 2015). The idea was to help librarians develop their collections and to help readers better identify the journals of a discipline. Nearly decade later, in 1973, Erzhong Wu introduced a core journal list for chemistry, which was the first mention of the concept of a "core journal" (Wu, 1973). Also a Western construct, core journals are those that publish a large number of papers in a certain discipline, and the notion is useful for identifying high-quality professional journals that can represent the development level of the discipline and are valued by the readers. Fast forward to 1982, when Liansheng Meng finished his Master's thesis entitled "Chinese science citation analysis" (Meng, 1982). His central premise was to establish a similar Chinese database to the SCI and then, in 1989, he built the Chinese Science Citation Index (CSCI), now called Chinese Science Citation Database (CSCD), with the support of the Documentation and Information Center of the Chinese Academy of Sciences. This 25-year journey established the foundations of journal evaluation in China for the natural sciences, which are still relevant today. In the 30 years since, China has adopted, adapted, investigated, and vigorously redeveloped the journal evaluation theories of the West, particularly the concepts of core-area journals and impact factors. However, what began as a useful framework for librarians has gradually been transfigured into an academic performance and ranking system that dictates everything from tenure decisions to grant funding to the best parking spots on campus (Shu et al., 2020).

Chinese journal evaluation in the social sciences is an essential part in the practice of journal evaluation in China. However, the early studies mainly focused on the evaluation of academic journals in the natural sciences by bibliometric methods to select the core journals, and rarely involved the evaluation of academic journals in the social sciences, since the beginning of academic journal evaluation studies in China in the 1960s (Jing et al., 2015). After the 1990s, studies on the evaluation of social science journals have emerged gradually and presented a trend of diversification (Guo \& Jing, 2016; Jing et al., 2015). Generally speaking, the journal evaluation system of the social sciences has been gradually formed in the process and it includes two parts, namely, the system of awards for social science journals from government departments, and the system of evaluation of social science journals by academic evaluation institutions. The key events in this development process are shown in Table 1. 
Table 1. A brief history of social science journal evaluation in China

\begin{tabular}{|l|l|}
\hline Year & Events \\
\hline 1992 & $\begin{array}{l}\text { Peking University Library launches the first edition of "A Guide to the Core Journals of China" } \\
\text { (GCJC), which covers the natural sciences, the social sciences, medicine, agricultural science, } \\
\text { and engineering science. }\end{array}$ \\
\hline 1995 & $\begin{array}{l}\text { The National Press and Publication Administration (NPPA) hosts the first journal selection } \\
\text { event - the "Selection of National Social Science Journal". }\end{array}$ \\
\hline 1996 & $\begin{array}{l}\text { The Chinese Academy of Social Sciences (CASS) begins selecting journals for the "Chinese } \\
\text { Core Journals in Humanities and Social Sciences". }\end{array}$ \\
\hline 1997 & Nanjing University begins building the "Chinese Social Sciences Citation Index" (CSSCI). \\
\hline 2098 & $\begin{array}{l}\text { NPPA selects the first titles for the "National Top 100 Key Social Science Journals" list. } \\
\text { Famous Journals of Philosophy and Social Sciences in Colleges and Universities". }\end{array}$ \\
\hline 2009 & $\begin{array}{l}\text { Wuhan University begins to regularly publish the "Research Center for Chinese Science } \\
\text { Evaluation (RCCSE) Core Journals", covering all fields. }\end{array}$ \\
\hline 2012 & $\begin{array}{l}\text { The National Social Sciences Fund of China (NSSFC) funds the selection of academic } \\
\text { journals in social sciences. }\end{array}$ \\
\hline 2015 & $\begin{array}{l}\text { The Chinese Evaluation Center for Humanities and Social Sciences (CECHSS) of CASS } \\
\text { launches the "Report of Journals Evaluation in Chinese Humanities and Social Sciences" for } \\
\text { the first time. }\end{array}$ \\
\hline $\begin{array}{l}\text { NPPA issues a "Notice on the Recommended Activities of the Top 100 Newspapers, Top 100 } \\
\text { Social Science Journals and Top 100 Science and Technology Journals in 2015". }\end{array}$ \\
$\begin{array}{l}\text { The Chinese Academy of Social Sciences Evaluation Studies (CASSES) of CASS launches } \\
\text { the "Attraction, Management and Influence" Comprehensive Evaluation Report (AMI) based } \\
\text { on the edition launched in 2014. }\end{array}$ \\
\hline
\end{tabular}

Note: Partly refer to (Guo \& Jing, 2016).

What Table 1 shows is that both government-managed institutions, such as the NPPA, MOE and NSSFC, and academia, e.g., the Peking University Library, CASS, and Wuhan University, have played essential roles in the development of journal evaluation for the social sciences. They have organized and engaged in many journal evaluation activities and promoted the development of the resulting systems. What the table does not show, however, is that many participating trade associations and database publishers have also been key voices in this process - for example, the information publisher, China National Knowledge Infrastructure (CNKI), and the China Association for Science and Technology (CAST) (Research Group of China Academy of Press and Publication et al., 2020).

In the ever-changing environment of scientific research evaluation, the research and practice of journal evaluation in China is evolving to meet different needs (Huang et al., 2021), but policy also needs to play a role in this development. Table 2 shows some of the policies and activities relevant to journal evaluation for the social sciences over the last 25 years (Guo \& Jing, 2016; Su, 2019). 
Table 2. Related policies and activities about the evaluation of social science journals (selected)

\begin{tabular}{|c|c|c|c|c|}
\hline No. & Policy documents or activities & Authority & Detail or Significance & Date \\
\hline 1 & $\begin{array}{l}\text { Quality standards and quality evaluation methods } \\
\text { for social science journals (trial) } \\
\text { 《社会科学期刊质量标准及质量评估办法（试 } \\
\text { 行)》 }\end{array}$ & NPPA & $\begin{array}{l}\text { The social science journals were divided into four categories: academic theory, } \\
\text { current affairs and politics, education, and comprehensive cultural life. The } \\
\text { quality evaluation scheme consisted of four parts: political standards, operational } \\
\text { standards, editorial standards, and publishing standards. }\end{array}$ & 1995.06 \\
\hline 2 & $\begin{array}{l}\text { Quality management standards for social science } \\
\text { journals (trial) } \\
\text { 《社会科学期刊质量管理标准 (试行)》 }\end{array}$ & NPPA & $\begin{array}{l}\text { The quality assessment criteria were proposed for administrative departments to } \\
\text { use to review, evaluate, and grade social science journals. }\end{array}$ & 1995.06 \\
\hline 3 & $\begin{array}{l}\text { First selection of the "National Top } 100 \text { Key } \\
\text { Social Science Journals” } \\
\text { 《首届“全国百种重点社科期刊”评选》 }\end{array}$ & NPPA & $\begin{array}{l}\text { For the first time, the evaluation criteria included economic indicators, such as } \\
\text { circulation. This decision was to underpin future journal evaluation systems. }\end{array}$ & 1997.02 \\
\hline 4 & $\begin{array}{l}\text { Some opinions on the further development and } \\
\text { prosperity of philosophy social sciences in } \\
\text { colleges and universities } \\
\text { 《教育部关于进一步发展繁荣高校哲学社会科 } \\
\text { 学的若干意见》 }\end{array}$ & MOE & $\begin{array}{l}\text { Some opinions were given about how to strengthen and promote journals for the } \\
\text { liberal arts, philosophy, and social sciences. The goal was to establish a significant } \\
\text { number of first-class and internationally-renowned journals in the social sciences. }\end{array}$ & 2003.02 \\
\hline 5 & $\begin{array}{l}\text { Implementation plan of the project of the famous } \\
\text { journals of philosophy and social sciences in } \\
\text { colleges and universities } \\
\text { 《教育部高校哲学社会科学名刊工程实施方案 } \\
\text { 》 }\end{array}$ & MOE & $\begin{array}{l}\text { The plan aimed to gradually change the status quo of journals in the social } \\
\text { sciences from "comprehensive, scattered, niche and weak" to "professional, } \\
\text { famous, special and powerful". }\end{array}$ & 2003.11 \\
\hline 6 & $\begin{array}{l}\text { Project for enhancing the international impact of } \\
\text { China STM journals } \\
\text { 《中国科技期刊国际影响力提升计划》 }\end{array}$ & $\begin{array}{l}\text { CAST; MOF; MOE; } \\
\text { SAPPRFT (now, } \\
\text { NRTA); CAS; CAE }\end{array}$ & $\begin{array}{l}\text { The program focused on supporting many English-language } \\
\text { scientific, technical and medical (STM) journals of high academic quality and } \\
\text { with strong international influence. }\end{array}$ & 2013.09 \\
\hline 7 & $\begin{array}{l}\text { Some opinions on the role of STM journals in the } \\
\text { academic evaluation } \\
\text { 《关于准确把握科技期刊在学术评价中作用的 } \\
\text { 若干意见》 }\end{array}$ & $\begin{array}{l}\text { CAST; MOE; } \\
\text { SAPPRFT (now, } \\
\text { NRTA); CAS; CAE }\end{array}$ & $\begin{array}{l}\text { Suggestions were made for using ranking and evaluation lists of scientific } \\
\text { journals more appropriately within academic performance evaluations. }\end{array}$ & 2015.11 \\
\hline 8 & $\begin{array}{l}\text { Guiding opinions concerning reform of the } \\
\text { categorized promotion of talent evaluation } \\
\text { mechanism《关于分类推进人才评价机制改革 } \\
\text { 的指导意见》 }\end{array}$ & $\begin{array}{l}\text { General Office of the } \\
\text { CPC Central } \\
\text { Committee; GOSC }\end{array}$ & $\begin{array}{l}\text { The guidelines stipulated that, when conducting performance evaluations, } \\
\text { institutions should adhere to the principle of classification evaluation. When } \\
\text { appraising academic's publishing record, institutions should set evaluation } \\
\text { indexes reasonably and not solely base academic merit on the journal's impact } \\
\text { factor (IF). }\end{array}$ & 2018.02 \\
\hline 9 & Several opinions on further strengthening & General Office of the & These were opinions on establishing a management and early warning system for & 2018.05 \\
\hline
\end{tabular}




\section{scientific integrity}

《关于进一步加强科研诚信建设的若干意见》

10 Opinions on the deepening of reform on project review, talent evaluation and institution assessment《关于深化项目评审、人才评价、 机构评估改革的意见》
CPC Central

Committee; GOSC

\section{General Office of the Suggestions that:}

CPC Central

Committee; GOSC

(1) The tenure of scholars in journals, such as editors-in-chief, editorial board

members, and journal reviewers, should be used as important evaluation indicators.

(2) An early warning monitoring system for academic journals needs to be

established, and the early warning lists and blacklists of academic journals need to be regularly published.

(3) The number of papers included in the SCI (Science Citation Index) and core journal, citations, and impact factors should only be used as references in academic evaluations, if the scholar is engaged in social welfare research or the development of applied technology.

11 Opinions on deepening reform and cultivating world-class STM journals 《关于深化改革培育世界一流科技期刊的意见

CAST; CPCPD;

MOE; MOST compile " "catalogue of key constuction jou

These measures sought to improve China's science and technology evaluation system by rejecting the incorrect notion that papers are the only criterion for assessing research performance. Classification evaluation would be implemented, which focuses on the research quality, contributions, and impact of landmark achievements by researchers.

2 Some measures to eliminate the bad orientation of MOST "papers only" in science and technology evaluation (trial) 《关于破除科技评价中“唯论文”不良导向的若 干措施(试行)》

13 Some suggestions on standardizing the use of SCI MOE; MOST paper indexes in higher educational institutes and establishing correct evaluation orientation 《关于规范高等学校SCI论文相关指标使用 树立正确评价导向的若干意见》

The document made suggestions for regulating the use of indicators related to SCI 2020.02 papers in various evaluation work, encouraging a comprehensive evaluation method, combining qualitative and quantitative indicators, exploring the idea of establishing a scientific evaluation system, and guiding the evaluation work to highlight scientific spirit, innovation quality, and service contribution.

Note: National Press and Publication Administration (NPPA); Ministry of Education of the People's Republic of China (MOE); China Association for Science and Technology (CAST); State Administration of Press, Publication, Radio, Film and Television of the People's Republic of China (SAPPRFT), and it was renamed as National Radio and Television Administration of the People's Republic of China (NRTA) in 2018; Ministry of Finance of the People's Republic of China (MOF); Chinese Academy of Sciences (CAS); Chinese Academy of Engineering (CAE); General Office of the State Council of the People's Republic of China (GOSC); Ministry of Science and Technology of the People's Republic of China (MOST); Communist Party of China (CPC); Publicity Department of the CPC Central Committee (CPCPD) 
In 1995, the government, via the National Press and Publication Administration (NPPA), first decided to implement policies related to journal evaluation for the social sciences. These were established as official standards for evaluating journal quality. Soon after, the NPPA began to organize a journal selection program to assemble the "National Top 100 Key Social Sciences" journals. For all practical purposes, this was when most scholars began to understand that journal evaluation was government business. In 2003, the MOE issued two documents to guide universities and colleges in developing social science journals.

Taking a moment to examine the bigger picture for all disciplines and not just the social sciences, overall, the journal lists and ranking systems devised by academic institutions, such as the Peking University, Nanjing University, and Wuhan University and CASS, had attracted wide attention, but much of it was critical. The majority of concern was over the evaluation results of core journals and their function as academic evaluation tools.

These replacement policies were intended to restore China's international influence and attract more international readers, especially in the scientific, technical, and medical (STM) disciplines. This meant launching English-language journals, and this was what the policies of the next ten years would support. The "Market Journals Report" of the UK's Publishers Association (PA) at the time stated that new English-language journals were "springing up like mushrooms" in China as a result of these new policy initiatives, with STM titles seeing a particular boom (Anderson, 2016). There are also some attempts and efforts being made by institutions in the evaluation of English-language journals in the social sciences. For example, the AMI journal list published by CASSES contains journal evaluation results in respect of English journals.

The government has now issued several documents involving journal evaluation, with new requirements for evaluating social science journals. From 2018 on, there has been a policy pushing to reduce the excessive emphasis on the number of papers that an academic has published and the impact factors of the journals they were published in. On the one hand, the general principle behind the design of the evaluation indicators is that they should reflect: the originality of the papers; the editorial quality of the journal, which shows the quality of all the work done by the editor, such as topic selection, the editing process, and the market feedback for journals; and the quality of the review system's construction; the caliber and experience of the editorial team should be also considered ( $\mathrm{Su}, 2019)$. On the other hand, the general principle behind having an evaluation system at all is that lists of both blacklisted and consummate journals are necessary to promote further development in journals and to optimize the academic ecology ( $\mathrm{Su}, 2019)$.

Based on the above introduction to the history and new policy environment, the following sections of this chapter will focus on the comparative analysis of the main 
Chinese journal evaluation systems in the social sciences. Also, we will discuss the limitations of these social science journals' evaluation systems and suggest some possible improvements. Overall, the aim of this study is to present and review the progress of the social science journal evaluation systems in China and present a comprehensive analysis of the current state of the art. The study will not only offer a deeper understanding of China's journal evaluation practices in the social sciences but also provide some meaningful insights to the journal evaluation activities of other countries.

\section{Main Chinese journal evaluation systems in social sciences}

During these few decades of development, several institutions in China have established comprehensive journal evaluation systems that combine quantitative and qualitative indicators, many of which have had a significant influence on research activity (Huang et al., 2021). Our treatise begins with the two most influential of these systems in the social sciences: the CSSCI journal list from the Institute for Chinese Social Sciences Research and Assessment (ICSSRA) at Nanjing University, and the AMI journal list from the Chinese Academy of Social Sciences Evaluation Studies (CASSES).

\subsection{The CSSCI journal list}

\subsubsection{Background}

Nanjing University began developing the CSSCI in 1997 and launched it in 2000. The purpose of the index is to provide an efficient repository of information about Chinese knowledge innovation and cutting-edge research in the social sciences, coupled with a comprehensive evaluation of China's academic influence in these areas ( $\mathrm{Su}$ et al., 2012; Su et al., 2001). The project was born out of a long-standing initiative by ICSSRA which had given rise to several citation databases in the social sciences, including an older version of the CSSCI, the Chinese Book Citation Index (CBKCI), the Chinese Social Sciences Citation Index (Extended Edition), and the Academic Collection Citation Index, and the Hong Kong, Macao, Taiwan and Overseas Chinese Citation Index (ICSSRA, 2020). Today, it is commonly used as a reference for academic performance appraisal, management, and research (Chen, 2013; Research Group of China Academy of Press and Publication et al., 2020).

The CSSCI catalogues citations from 782 Chinese journals across 25 major disciplines in the humanities and social sciences, including law, management, economics, history, political science, etc. It is built on a combination of quantitative and qualitative methods and, as of 2017, it contained more than 1.5 million source documents and more than 10 million citation documents (ICSSRA, 2016). The data in CSSCI is constantly updated, as are the journals on its core list. However, since figures beyond 2017 are not readily 
available, it would seem that the database itself is updated more regularly than the website that provides information about it. As of 2019, the CSSCI was in its 12th edition.

\subsubsection{Journal selection criteria}

The selection criteria for the 12th edition of CSSCI (2019-2020) are summarized below (CSSCI editorial department, 2018; ICSSRA, 2019).

(1) Journal scope. Journals are eligible for inclusion in the CSSCI if they publish or collate Chinese articles on the humanities and social sciences either at home or abroad. In addition, a journal must meet the following basic requirements (CSSCI editorial department, 2018; Huang et al., 2021).

- The journal must be Chinese and publish mainly original academic articles or reviews on the social sciences.

- Journals published in mainland China must have a CN number. Journals published in Hong Kong, Macao, and Taiwan must have an ISSN number, and academic collections must have an ISBN.

- The journal must be published according to a regular publishing cycle and must conform to journal editing and publication standards with complete and standardized bibliographic information.

(2) Evaluation methods and indicators. The indicators are both quantitative and qualitative but mainly include two-year impact factors (excluding self-citations), and the total number of citations (Research Group of China Academy of Press and Publication et al., 2020). The data sources for indicators are mostly self-collected data; however, the CSSCI does rely on expert evaluators to rate each journal against five main items political quality, academic quality, editorial and publication quality, plus an overall evaluation - as well as 16 additional subitems (Chen, 2013).

(3) Evaluation results. The journals are categorized into 25 disciplines $1-23$ are subject-specific and two are general categories, one for multidisciplinary university journals and the other for multidisciplinary social science journals (Huang et al., 2021). The university journals are comprehensive journals or other journals that mainly publish social science papers, which are sponsored by universities, whereas as the social science journals are comprehensive journals/book review journals sponsored by public finance, professional associations, and so on. A full list is given in Appendix Table A1. The 12th edition contains 568 core journals plus 214 more on the extended list (ICSSRA, 2019). Extended journals are also called candidate journals in the CSSCI source journal, and those may be transferred to the core list in the next evaluation. 


\subsection{The AMI journal list}

\subsubsection{Background}

The AMI journal list is managed by CASSES, a centre established in July 2017 out of the Chinese Evaluation Center for Humanities and Social Sciences (CECHSS). The Center has been investigating papers in the humanities and social sciences since 1996, and, in 2001, it successfully developed the Chinese Humanities and Social Sciences Citation Database (CHSSCD) in cooperation with CNKI. Using this database as a data source for statistical analysis, CASSES devised a series of journal evaluation systems for Chinese journals based on the characteristics of the disciplines. It then produced a comprehensive evaluation report of Chinese HSS journals, titled "A Comprehensive Evaluation Report on the AMI of Chinese Humanities and Social Science Journals" (or simply AMI for short).

The purpose of the AMI list is to focus on formative evaluation "to help and improve" rather than perform a summative evaluation "to judge" a journal's quality. Another goal is to increase the recognition of journals in HSS by collaborating nationally across institutions rather than competing to support useful journals. AMI's basic principle is to provide well-informed judgments about journals, not simple indicators, that provide reliable advice on where to publish. This principle is well reflected in its evaluation methods and indicator system.

To date, AMI reports have been published in 2014 and 2018. However, the list's history can be dated as far back as 1999, and it also has strong ties to the three editions of "A Guide to the Core Journals in Chinese Humanities and Social Sciences" published in 2004, 2008, and 2013 (Chen, 2013). Uniquely, CASSES provides evaluations on both new journals (defined as less than five years old) and English-language journals published in China. At present, no other domestic journal evaluation includes these types of journals.

\subsubsection{Journal selection criteria}

The AMI list is updated every four years. It combines quantitative indicators with qualitative expert evaluations. The selection criteria for inclusion on the list are summarized below (Chinese Academy of Social Sciences, 2018; Su, 2019).

(1) Journal scope. The range of candidates for the AMI list includes more than 2000 HSS journals, most of which were inherited from the former SAPPRFT indexes, published in 2014 and 2017 (SAPPRFT, 2014, 2017). It also includes English-language journals and "new" journals, that is, journals founded between 2013 and 2017.

(2) Evaluation methods and indicators. The ranking system comprises three main evaluation metrics - attraction, management power, and influence - weighted by a ratio of $0.35 / 0.2 / 0.45$, respectively. Attraction is a measure of the journal's external 
environment, e.g., its reputation among readers and researchers, its ability to acquire external resources and so on. Management power refers to the ability of the editorial team to promote the journal's development. Influence represents the journal's academic, social, and international influence, which is affected by the other two metrics. In addition to these three indicators, there are a further ten second-level indicators and 24 third-level indicators, as shown in Table 3. Looking closely at the list, one can see that most of the quantitative indicators draw data from other sources. Data to inform the remaining qualitative indicators is drawn from a broad survey and follow-up interviews. Information about the second-level indicators comes from peer reviews, and information about thirdlevel indicators comes from expert members, recommended experts, researchers, and managers. Notably, the opinions of each of these groups are allocated a different weight.

(3) Evaluation results. The current list comprises 1291 Chinese journals, 164 new journals, and 68 English-language journals, divided into three broad subject categories, 23 sub- categories, and 33 sub-subcategories. Table A2 in the Appendix provides a full list. The categories are based on university degrees and other classifications in the academic training directory published by the MOE, plus the classification and GB/T 13745-2009 disciplines codes in the Chinese Library Classification (fifth edition). Moreover, the reports divide the journals into five categories: the top journals (5), authoritative journals (56), core journals (546), extended journals (711), and indexed journals (179) (Chinese Academy of Social Sciences, 2018). And 26 English journals without $\mathrm{CN}$ have not been evaluated; journal assessment agencies only employ these journals as observational objects, analyzing some of their properties and characteristics, but not as evaluation targets. 
Table 3. Quantitative indicators of AMI journal list

\begin{tabular}{|c|c|c|c|}
\hline \multirow{2}{*}{$\begin{array}{l}1^{\text {st }} \text { level } \\
\text { Indicator }\end{array}$} & \multicolumn{2}{|l|}{$2^{\text {nd }}$ level Indicator } & \multirow[b]{2}{*}{$3^{\text {rd }}$ level Indicator } \\
\hline & Name & Type & \\
\hline \multirow{8}{*}{$\begin{array}{l}\text { Attraction } \\
0.35\end{array}$} & \multirow{2}{*}{ Award status } & \multirow{2}{*}{$S$} & Awards received by journals and editors \\
\hline & & & Awards received by publications \\
\hline & \multirow{3}{*}{ Publication } & \multirow{3}{*}{$S$} & Funded paper ratio $^{\text {a }}$ \\
\hline & & & Open access \\
\hline & & & Download frequency \\
\hline & \multirow{3}{*}{ Peer review } & \multirow{3}{*}{$S$} & Expert committee members \\
\hline & & & Suggested experts \\
\hline & & & Scientific researchers and administrators \\
\hline \multirow{8}{*}{$\begin{array}{l}\text { Management } \\
0.20\end{array}$} & Academic misconduct ${ }^{\mathrm{b}}$ & $\mathrm{O}$ & \\
\hline & \multirow{2}{*}{$\begin{array}{l}\text { Editorial team and author } \\
\text { group }\end{array}$} & \multirow{2}{*}{$\mathrm{N}$} & Editorial team \\
\hline & & & Author group \\
\hline & \multirow{2}{*}{ Institutional regulation } & \multirow{2}{*}{$\mathrm{S}$} & System construction \\
\hline & & & Editor specification \\
\hline & \multirow{3}{*}{ Informalization construction } & \multirow{3}{*}{$S$} & Website construction \\
\hline & & & The online manuscript processing system \\
\hline & & & WeChat public account \\
\hline \multirow{9}{*}{$\begin{array}{l}\text { Influence } \\
0.45\end{array}$} & \multirow{5}{*}{ Academic influence } & \multirow{5}{*}{$\mathrm{S}$} & Journal immediacy index \\
\hline & & & 2-Year JIF \\
\hline & & & 5-Year JIF \\
\hline & & & Reprint ratio \\
\hline & & & $\begin{array}{l}\text { The ratio of cited journals from the given } \\
\text { categories or external categories }\end{array}$ \\
\hline & \multirow{2}{*}{ Social influence } & \multirow{2}{*}{$\mathrm{N}$} & Circulation \\
\hline & & & Online propagation capability \\
\hline & \multirow{2}{*}{ International influence } & \multirow{2}{*}{$\mathrm{N}$ or $\mathrm{S}$} & Overseas distribution \\
\hline & & & Cited by foreign journals \\
\hline
\end{tabular}

Note: The indicator type $\mathrm{S}$ means measurements add to the total score; $\mathrm{O}$ means measurements will reduce the total score; $\mathrm{N}$ means measurements do not affect the score in the current edition.

${ }^{a}$ This refers to the proportion of papers that are funded by national funds in a journal.

${ }^{\mathrm{b}}$ This indicator is a point deduction indicator. If there is no academic misconduct, the score is “ 0 " ; rather, if there is such behavior, points will be deducted.

\subsection{Comparative analysis of CSSCI and AMI journal list}

What is clear from the descriptions of the two major social science journal lists is that each was established to fill specific objectives, and has its own selection criteria, yet there may be as many similarities between these two systems as there are differences. These are summarized in Table 4. 
Table 4. Comparison between CSSCI and AMI

\begin{tabular}{|c|c|c|c|}
\hline \multicolumn{2}{|l|}{ 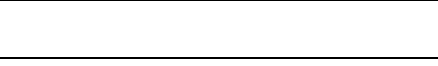 } & CSSCI & AMI \\
\hline \multicolumn{2}{|l|}{ Producer } & ICSSRA, Nanjing University & CASSES, CASS \\
\hline \multicolumn{2}{|l|}{ Release year } & 1998 & 2014 \\
\hline \multicolumn{2}{|c|}{ Update frequency } & $\begin{array}{l}\text { Biennially (2003-); yearly (before } \\
\text { 2003) }\end{array}$ & Quadrennial \\
\hline \multirow{4}{*}{$\begin{array}{l}\text { Indexed } \\
\text { journals }\end{array}$} & Scopes & Domestic & Domestic \\
\hline & Language & Chinese & Chinese, English \\
\hline & $\begin{array}{l}\text { Research } \\
\text { areas }\end{array}$ & Arts \& humanities; social sciences & $\begin{array}{l}\text { Arts \& humanities; social } \\
\text { sciences }\end{array}$ \\
\hline & $\begin{array}{l}\text { Identification } \\
\text { numbers }\end{array}$ & ISSN or CN & $\mathrm{CN}$ \\
\hline \multicolumn{2}{|c|}{ Evaluation purposes } & $\begin{array}{l}\text { Provide a reference for evaluation, } \\
\text { performance appraisal, } \\
\text { management, and research }\end{array}$ & $\begin{array}{l}\text { Help to improve journal quality } \\
\text { and increase the recognition of } \\
\text { journals in HSS }\end{array}$ \\
\hline \multirow[t]{2}{*}{$\begin{array}{l}\text { Quantitative } \\
\text { evaluation }\end{array}$} & Indicators & $\begin{array}{l}\text { 2-year JIF (exclude self-citation), } \\
\text { total times cited, etc. }\end{array}$ & $\begin{array}{l}\text { Attraction, management power, } \\
\text { and influence }\end{array}$ \\
\hline & Data sources & $\begin{array}{l}\text { Self-built and self-collected data } \\
\text { (e.g., CSSCI) }\end{array}$ & $\begin{array}{l}\text { The self-built and self-collected } \\
\text { data of CASSES (e.g., } \\
\text { CHSSCD), the third-party data, } \\
\text { and the self-evaluated data of the } \\
\text { journal editorial department }\end{array}$ \\
\hline \multicolumn{2}{|c|}{ Qualitative evaluation } & $\begin{array}{l}\text { Five major items (political quality, } \\
\text { academic quality, editorial and } \\
\text { publication-quality, overall } \\
\text { evaluation, etc.), } 16 \text { subitems }\end{array}$ & $\begin{array}{l}\text { Peer review (expert members, } \\
\text { recommended experts, and } \\
\text { researchers and managers) }\end{array}$ \\
\hline \multirow{3}{*}{$\begin{array}{l}\text { Evaluation } \\
\text { results }\end{array}$} & Number & $782(2019)$ & $1523(2018)$ \\
\hline & Disciplines & 25 disciplines & $\begin{array}{l}\text { Three broad subject categories, } \\
23 \text { subject categories, and } 33 \\
\text { subject subcategories }\end{array}$ \\
\hline & Grades & $\begin{array}{l}\text { Core source journals; } \\
\text { extended source journals }\end{array}$ & $\begin{array}{l}\text { Top journals; authoritative } \\
\text { journals; core journals; extended } \\
\text { journals; indexed journals }\end{array}$ \\
\hline
\end{tabular}

CSSCI and AMI differ in both the scope of the journals they cover and their selection criteria. Unlike CSSCI, the AMI list includes English journals. In addition, CSSCI requires that the candidate journal has an ISSN, or a $\mathrm{CN}$ identification number if its scope is limited to Mainland China, Hong Kong, Macao, and Taiwan.

Although both CSSCI and AMI combine quantitative evaluation with expert qualitative evaluation, the indicators and data sources they are based on vary greatly. CSSCI mainly uses bibliometric indicators to assess quality, whereas AMI uses a comprehensive set of indicators designed to help improve a journal's quality over time. Another similarity is that both indicators are based on information largely produced by the index's own developer. In terms of qualitative evaluation, there are some differences between the two expert reviews, but it is difficult to judge which one is better from the 
few details of the indicators provided.

In terms of sheer numbers, AMI indexes more journals than CSSCI. Additionally, AMI's grading system is more complicated. It divides journals into three categories - Ajournals, new journals, and English-language journals - then further subdivides the Ajournals into five levels of quality. CSSCI is simply divided into two levels - core journals and extended journals.

\section{Other Chinese journal evaluation systems in the social sciences}

Most of the other journal evaluation systems in China are produced by academics or those closely aligned with scholarship. Some of the more notable include "A Guide to the Core Journals of China" (GCJC) by the Peking University Library, the Research Center for Chinese Science Evaluation (RCCSE) Index by Wuhan University, the social sciences volume of the Chinese Science and Technology Journal Citation Reports (CJCR), and the FMS Journal Rating Guide (Federation of Management Societies of China), published by the China Association for Science and Technology (CAST). GCJC and RCCSE both conduct comprehensive evaluations of journals in the humanities, social sciences and natural sciences. CJCR (Social Sciences Volume) only pertains to the humanities and social sciences. The FMS covers international and Chinese journals in management science.

\subsection{The GCJC journal list - Peking University Library}

GCJC is a research project conducted by researchers at the Peking University Library and a dozen other university libraries, and experts from other institutions around China. In general, the guide is used by library intelligence departments as a reference to purchase and reserve books and to help tutors create reading lists (The Committee for a Guide to the Core Journals of China, 2018). The list's publisher emphasizes that core journals cannot be used to comprehensively evaluate the quality of journals; nor should the list be used as a basis for scholarly evaluation (Chen et al., 2018; Research Group of China Academy of Press and Publication et al., 2020). In accordance with the dynamic development of journals, the guide is regularly updated and has been published every four years since 1992 and every three years since 2011. It is only published as a printed book. Up to now, eight editions have been published by Peking University Press.

The latest 2020 edition of the journal list was published in 2021, with all Chinese journals published in mainland China eligible for evaluation, including academic journals, other literary works such as fiction, poetry, or essays, and popular-science periodicals. The quantitative evaluation process consists of $10+$ bibliometric indicators. Moreover, this index boasts the most abundant data sources for indicators, covering both Chinese 
and foreign databases, such as CSTPCD, CSSCI, Wanfang Data Knowledge Service Platform (Wanfang), China Science and Technology Journal Database (VIP), Scopus, and Social Sciences Citation Index (SSCI). The evaluation results are based on quantitative evaluations, supplemented by the opinions of experts and scholars. The 2020 edition of GCJC contains 1990 core journals across the humanities, social sciences, and natural sciences, assigned to 74 disciplines.

\subsection{The RCCSE journal list - RCCSE}

The RCCSE journal list has been published by the Research Center for Chinese Science Evaluation of Wuhan University since 2009. The list has two main purposes: (1) to provide the basis for scientific evaluation and management and to provide references to other evaluations, including project evaluation, outcome evaluation, talent assessment, and institution assessment; (2) to provide a reference for periodical procurement, collection optimization, and information services in library and information institutions. The RCCSE journal list is a comprehensive list of rankings for Chinese journals across multiple disciplines (Zhang \& Lun, 2019). The evaluated journals include both purely academic journals and semi-academic journals concerning the natural sciences or humanities and social sciences (Qiu et al., 2009). The general principles of evaluation are classification assessment and hierarchical management (Qiu, 2011). Roughly speaking, the report is updated every two years.

In the latest edition of RCCSE (2020), the journals spanned Chinese academic journals, university/college journals, and Chinese open access (OA) academic journals. Including semi-academic journals is a recent expansion to the index, and semi-academic journals have to meet a requirement that academic papers account for more than 50 percent of the total articles indexed in those journals (Chen, 2013). Candidate journals of RCCSE are first evaluated quantitatively. The RCCSE sets different indicator systems and weights according to the three original types of journals, i.e., academic journals, university journals, and OA journals. Further, the list is divided into 65 disciplines across the humanities, social sciences, and natural sciences. The Chinese journals are ranked as either A+ (authoritative), A (core), A- (core), B+, B, or C. The university/college journals and $\mathrm{OA}$ journals cannot receive an $\mathrm{A}+$ ranking.

\subsection{The CJCR (Social Sciences Volume) - ISTIC}

The Institute of Scientific and Technical Information of China (ISTIC) gathers statistics from the China Scientific and Technical Papers and Citations Database (CSTPCD) and produces an annual statistical report on various categories of the nation's academic 
progress and scientific output. The report provides a wealth of information and decision support for government administration departments, colleges and universities, research institutions, and researchers. It is used for quantitative analysis and to explore the characteristics or discipline status of journals as a basis for scientific research management (Research Group of China Academy of Press and Publication et al., 2020). Although the CJCR has a long history, this initially only extends to journals in the natural sciences. The social science journals have only been indexed since 2016 when ITSIC integrated the CSTPCD database into the CJCR Social Sciences Volume.

The journals to be included in the analysis are selected through a rigorous peer review and quantitative evaluation process. Hence, they are regarded as important scientific and technical journals in China. The journal list of CJCR is based on multiple indicators, mostly bibliometric, and a combination of quantitative and qualitative methods. Specific indexes include citation frequency, impact factors, important database collection, and overall evaluation score (Ma, 2019). The CSTPCD citation database is the primary statistical source for indicators. The qualitative evaluation mainly relies on the experts who score the weights for important indicators and then evaluate each journal by discipline. Currently, the list includes 2049 journals (1933 Chinese-language and 116 English-language) in the fields of the natural sciences, engineering, and technology, as well as 395 journals in the social sciences (Institute of Scientific and Technical Information, 2019). Those 395 journals are distributed across 40 social science disciplines.

\subsection{Journal lists suggested by professional associations}

CAST has been publishing a ranking catalogue of high-quality STM journals since 2019, hoping to encourage the academic community to form a consensus on journal quality. In May 2019, the Chinese Society of Optimization, Overall Planning and Economical Mathematics, the Society of Management Science and Engineering of China, and the Systems Engineering Society of China have jointly released the recommended list of high-quality journals in management science which was named the FMS Journal Rating Guide (Federation of Management Societies of China). The detailed process of researching the FMS Journal Rating Guide can be found at its official website (www.fms-journal.net/english?lang=en_us). Finally, 1135 high-quality international journals in management science are recommended in the FMS Journal Rating Guide, which includes 133 A journals, 319 B journals, 444 C journals, and 239 D journals.

\subsection{School or departmental journal lists}

As academic journals proliferate, administrators and research managers are constantly looking for ways to improve the efficiency of their assessment processes. Many construct 
their own school or departmental lists to help evaluate faculty research (Beets et al., 2015), with business schools particularly using internal journal lists to inform promotion and tenure decisions (Bales et al., 2019). Indeed, most of the universities with government funding have created internal journal lists to help evaluate faculty performance ( $\mathrm{Li}$ et al., 2019).

\section{Conclusion and discussion}

Evaluation systems for academic journals reflect how new insights are critically reviewed and published. Additionally, the prestige and impact of a discipline's journals inform many research assessments, performance evaluations, and funding systems (Huang et al., 2021). Chinese researchers are now the largest contributor to international journals indexed by the Web of Science (Zhang et al., 2021) - and the social science journal evaluation systems in China have positively promoted journal development and academic innovation. These systems differ in their evaluation methods and metrics, depending on their evaluation purposes. However, some general issues deserve consideration. We will discuss the limitations of these social science journal evaluation systems and suggest some possible improvements.

\subsection{Characteristics of the evaluation of social science journals in China}

The evaluation of social science journals in China has been shaped by national policies and conditions, discussed below.

First, the evaluative criteria of journals not only focus on academic quality and influence but also highlight political consciousness. Compared with the natural sciences, the social sciences are much more obviously ideological. Whether social science journals adhere to the correct political orientation and academic direction is of key interest in Chinese evaluations. Additionally, academic quality and influence, and editorial and publication standards, are also important. Thus, Chinese social science journal evaluation systems are based on bibliometric theories and expert opinions, as well as assessment by government departments.

Second, evaluating social science journals involves both quantitative and qualitative approaches. At present, many journal evaluation institutions adopt a mixed method, considering both quantitative indicators and expert opinions, although different institutions weight these quantitative and qualitative indicators in different ways according to the evaluation purpose. In general, quantitative indicators are not always the most valuable when assessing journal quality in the social science discipline - so expert opinions are widely considered to be important. For example, when CASSES evaluated HSS journals across 33 disciplines, the evaluation was informed by the opinions of 
several experts.

Third, social science journals largely use data from local citation databases. CSSCI, AMI, and CJCR (Social Sciences Volume) are specifically for the evaluation of social science journals, and each of them has their own citation database, namely CSSCI, CHSSCD and CSTPCD. Moreover, GCJC and RCCSE, which evaluate both natural science and social science journals, draw on a wide range of data sources but mostly rely on local citation data- bases. These local databases have been constructed gradually as journal evaluation has become more widespread, and at present, since most of the citation data for social science journals are Chinese, local databases are more important than international databases in the evaluation process.

Fourth, comprehensive journals are independently classified as a discipline. Unlike European and North American academic journals, most of which are serial publications publishing a series of papers in one subdiscipline, Chinese social science journals are frequently comprehensive (Zang, 2015). Due to the difficulty of classifying comprehensive journals into individual disciplines, evaluation institutions usually assess comprehensive journals separately (Geng, 2017). In the current cross-disciplinary research boom, how best to classify and evaluate comprehensive journals may be a worthy issue for journal evaluation institutions to consider.

\subsection{Limitations of social science journal evaluation in China}

Although current Chinese social science journal evaluation processes are generally robust, certain limitations persist. These are detailed below.

First, the existing evaluation systems designed for social science journals usually incorporate metrics more suited to evaluating humanities research. In China, the phrase "philosophy and the social sciences" is often used instead of "humanities and the social sciences" to refer to the soft disciplines (Feng et al., 2013). Both phrases imply an inextricable link between the humanities and the social sciences; thus, Chinese journal evaluation institutions usually evaluate journals from these highly distinct disciplines together, and there are a few evaluation systems that only assess social science journals. Indeed, most of the journal evaluation systems discussed in this study evaluate journals in both the humanities and the social sciences using the same standards. Only AMI sets different indicator weights according to journals' disciplines and characteristics.

This poses a problem. Since different disciplines have different research paradigms and journals in different disciplines may disseminate their citations differently, evaluating humanities and social science journals using the same criteria may result in inaccuracies. To address this issue, we must explore how social science journals with Chinese characteristics are evaluated. In general, China's social science journals have strong local 
characteristics. It is thus necessary for journal evaluation institutions to refer to international journal evaluation systems but also take into account local characteristics when weighing up evaluation indicators for social science journals (Yuan, 2014).

Second, social science journal evaluation systems are relatively unauthoritative. At present, Chinese social science journal evaluations are generally a joint effort between multiple evaluation agencies. There are two main social science journal lists and several comprehensive journal lists in China, each with its own evaluation objectives. As such, there is no monopoly on journal evaluation; there is no definitive ranking. While this offers many possibilities for developing evaluation processes, this dispersed system also means there is no unified and authoritative standard for social science journals. Additionally, because journal scopes are inconsistent, the discipline distribution across journals is unbalanced, and evaluation standards are not uniform, resources are easily wasted in assessing these journals and the resulting rankings may be unfair (Guo \& Jing, 2016). In short, the evaluations produced by multiple evaluation institutions may differ widely, which makes it difficult for the public to judge which one is most authoritative, and may mean some journals are unfairly represented. We contend that one comprehensive and authoritative journal list should be created as soon as possible, and advocate greater cooperation among the producers of different journal lists. These lists need to dynamically reflect the changing journal market, and the journal evaluations need to be clearly organized and informed by a range of inter-institutional expert advice. An authoritative national evaluation system would not only conserve resources but also increase the credibility and authority of a core journal list.

Third, how qualitative and quantitative factors are weighted in assessing journals is not transparent, but qualitative indicators seem to be more important overall. Currently, journal evaluation institutions rarely disclose detailed information about their journal selection processes, which tends to lead the public to doubt the evaluation results. This problem exists in all journal evaluations based on peer review. Therefore, we suggest it is necessary to increase the transparency of the social science journal evaluation process in order to increase reorganization of these journal lists. Measures that would increase transparency could include, for example, building a comprehensive, open review platform that could integrate the quantitative and qualitative data involved in journal evaluation, or establishing a set of scientific rules and impartial procedures to supervise evaluation institutions and discourage biased behaviors (Guo \& Jing, 2016). In addition, the quantitative indicators used to evaluate journal quality and influence are usually based on citation indicators, e.g., JIF, citation count, etc. However, social science and natural science research have different citation characteristics: social science journals take a longer time than natural science journals to receive citation data - so this is an unreliable 
metric for evaluation. Moreover, in quantitative evaluation, it is necessary to clarify the validity and necessity of different indicators clearly and identify whether there is a correlation between multiple indicators. Additionally, although expert ratings (that is, qualitative indicators) of specific journals are often suspected of being colored by personal bias, expert evaluation can produce robust macro-level results overall (Pölönen et al., 2020). Furthermore, creating an expert database for evaluating journals would greatly improve evaluation efficiency. Overall, it is necessary not only to combine quantitative and qualitative evaluation methods, but also to balance the weight of each in the evaluation process. Only in this way can we obtain relatively scientific and authoritative journal evaluation results.

\subsection{Implications of research assessment}

The study presents a comprehensive analysis of how social science journals are currently evaluated in China, taking into consideration the history, policies, and practices involved in the country's evaluation process. Most importantly, our discussion offers suggestions as to how social science journal evaluation could fruitfully develop in the future. In particular, we propose some solutions for journal evaluation institutions to improve the authority and efficiency of evaluation, such as establishing a unified evaluation process and making the weighting of qualitative and quantitative data in the evaluation process transparent. We also highlight that for research assessment departments, it is key to remember that journal evaluation institutions rank journals according to different criteria, with different purposes in mind. As such, any current one journal list should be treated as a single reference point rather than a gold standard.

\section{Acknowledgements}

We would like to thank Prof. Jinyan SU (CASSES) for providing valuable data and materials. This work is supported by the National Natural Science Foundation of China (Grant No. 72004169; 71974150; 71573085), and the National Laboratory Center for Library and Information Science in Wuhan University.

\section{NOTES}

1. The categories follow the Classification and Code of Discipline (GBT 13745-2009) from the Catalogue of Degree Awarding and Personnel Training (2011) and the Subject Classification Catalogue of the National Social Science Foundation in China. 


\section{References}

Anderson, P. (2016). UK's Publishers Association Reports on Journals in China. Publishing Perspectives. https://publishingperspectives.com/2016/08/uk-publishersassociation-china-journals/

Bales, S., Hubbard, D. E., Van Duinkerken, W., Sare, L., \& Olivarez, J. (2019). The use of departmental journal lists in promotion and tenure decisions at American research universities. The Journal of Academic Librarianship, 45(2), 153-161.

https://doi.org/10.1016/j.acalib.2019.02.005

Beets, S. D., Kelton, A. S., \& Lewis, B. R. (2015). An assessment of accounting journal quality based on departmental lists. Scientometrics, 102(1), 315 - 332.

https://doi.org/10.1007/s11192-014-1353-0

Chen, J., Zhu, Q., Zhang, J., \& Cai, R. (2018). 中文核心期刊要目总览（2017 年版) [A Guide to the Core Journals of China (2017 edn)]. Peking University Press.

Chen, R. (2013). 国内四种人文社科期刊评价体系的分析比较 [Analysis and comparison of four journals' evaluation systems of humanities and social sciences in China]. Library Work and Study, 1(4), 66 - 70.

Chinese Academy of Social Sciences. (2018). 中国人文社会科学期刊 AMI 综合评价 报告（2018 年）：A 刊评价报告 [Chinese Humanities and Social Sciences Journal AMI Comprehensive Evaluation Report].

http://ex.cssn.cn/xspj/xspj_yw/201811/t20181119_4777954.shtml

Committee for a Guide to the Core Journals of China. (2018). Research project on core journals. Peking University. www.lib.pku.edu.cn/portal/en/bggk/qikanyaomu

CSSCI editorial department. (2018). 《中文社会科学引文索引(CSSCI)》来源期刊 （集刊）遴选办法（试行）[The selection method of source journals (collections) of the “Chinese Social Science Citation Index (CSSCI)" (Trial)]. https://cssrac.nju.edu.cn/a/gywm/lxbz/20181015/7253.html

Feng, H., Beckett, G. H., \& Huang, D. (2013). From “import" to "import-export" oriented internationalization: the impact of national policy on scholarly publication in China. Language Policy, 12(3), 251-272. https://doi.org/10.1007/s10993-013-9285-8

Geng, H. (2017). 台湾地区人文社会科学期刊评价机制评析 [Research on journal evaluation in the area of Taiwan humanities and social science]. Journal of Intelligence, 36(04), 170 - 176. https://doi.org/10.3969/j.issn.1002-1965.2017.04.029

Guo, J., \& Jing, L. (2016). 中国人文社科期刊评价的变迁、问题及优化路径 [The changes, problems and optimization of the evaluation of Chinese journals in humanities and social sciences]. Journal of Intelligence, 35(1), $68-73,150$.

Huang, Y., Li, R., Zhang, L., \& Sivertsen, G. (2021). A comprehensive analysis of the journal evaluation system in China. Quantitative Science Studies, 2(1), 300-326. 
https://doi.org/10.1162/qss_a_00103 Institute for Chinese Social Sciences Research and Assessment. (2016). 中文社会科学引文索引（CSSCI）简介 [Introduction to the Chinese Social Science Citation Index (CSSCI)].

https://cssrac.nju.edu.cn/cpzx/zwshkxywsy/sjkjj/20191231/i63997.html

Institute for Chinese Social Sciences Research and Assessment. (2019). CSSCI 来源期 刊目录（2019-2020 年） [CSSCI source journal catalog (2019-2020). https://cssrac.nju.edu.cn/cpzx/ zwshkxywsy/20200814/i125597.html

Institute for Chinese Social Sciences Research and Assessment. (2020). 南京大学中国 社会科学研究 评价中心简介 [Introduction to the Institute for Chinese Social Sciences Research and Assessment of Nanjing University].

https://cssrac.nju.edu.cn/gywm/zxjj/index.html

Institute of Scientific and Technical Information. (2019). 《2019 年版中国科技期刊引 证报告》 [Chinese S\&T Journal Citation Report (2019 edition)]. Beijing: Scientific \& Technical Documentation Press.

Jing, L., Wang, L., Su, J., Lu, W., Geng, H., Yu, Q., Hao, R., Yang F., Xiang J., Guo, J. (2015). 中国 人文社会科学期刊评价:现状 - 问题 - 建议 [Evaluation of Chinese journals of humanities and social sciences: current situation, problems and suggestions]. China Social Science Review, (1), 79-84.

Li, J., Lu, X., Li, J., \& Wu, D. (2019). Evaluating journal quality by integrating department journal lists in a developing country: are they representative? The Journal of Academic Librarianship, 45(6), 1-10. https://doi.org/10.1016/j.acalib.2019.102067

Ma, Z. (2019). The relevance of national journals from a Chinese perspective. In W. Glänzel, H. F. Moed, U. Schmoch, \& M. Thelwall (eds), Springer Handbook of Science and Technology Indicators (pp. 505-562). Springer.

Meng, L. (1982). 中文科学引文分析 [Chinese science citation analysis]. Chinese Academy of Sciences.

Pölönen, J., Guns, R., Kulczycki, E., Sivertsen, G., \& Engels, T. C. E. (2021). National lists of scholarly publication channels: an overview and recommendations for their construction and maintenance. Journal of Data and Information Science, 6(1), 50-86. https://doi.org/10.2478/jdis-2021-0004

Research Group of China Academy of Press and Publication, Zhang, L., Dong, Y., \& Yang, C. (2020). 我国哲学社会科学学术期刊评价体系对比研究 [A comparative study of evaluation systems of academic journals of philosophy and social sciences in China]. Media, 4, 32 - 35.

Qiu, J. (2011). 期刊会议报告三、中国学术期刊评价的意义、做法与特色 [Journal Conference Report III: The significance, process and features of Chinese academic journal evaluation]. www.nseac.com/html/221/222923.html 
Qiu, J., Li, A., \& Shu, M. (2009). 中国学术期刊分类分等级评价的实证研究 [An empirical study on the classification and grading evaluation of Chinese academic journals]. China Publishing Journal, 4, 38 - 42.

Shu, F., Quan, W., Chen, B., Qiu, J., Sugimoto, C. R., \& Larivière, V. (2020). The role of Web of Science publications in China's tenure system. Scientometrics, 122(3), 16831695. https://doi.org/10.1007/ s11192-019-03339-x

State Administration of Press, Publication, Radio, Film and Television. (2014). 第一批 认定学术期刊名单正式公布 [The first list of recognized academic journals is officially announced]. www.gapp.gov.cn/news/1663/233978.shtml

State Administration of Press, Publication, Radio, Film and Television. (2017). 第二批 认定学术期刊名 单正式公布 [The second list of recognized academic journals is officially announced]. www.sapprft.gov.cn/sapprft/contents/6588/320556.shtml

$\mathrm{Su}$, J. (2019). 新政策视域下人文社会科学期刊评价设计与实施 [The design and implementation of evaluation of humanities and social science journals under new policies]. China Social Science Review, 3, 131 - 140, 144.

Su, X., Han, X., \& Han, X. (2001). Developing the Chinese Social Science Citation Index. Online Information Review, 25(6), 365-369.

https://doi.org/10.1108/EUM0000000006535

Su, X., Deng, S., \& Shen, S. (2012). The design and application value of the Chinese Social Science Citation Index. Scientometrics, 98(3), 1567-1582. https://doi.org/10.1007/s11192-012-0921-4

Wu, E. (1973). 世界化学类核心期刊 [World chemistry core journal]. World Book, $11-12$.

Yuan, B. (2014). 中国人文社科类学术期刊评价体系的科学构建 [Scientific construction of evaluation system for Chinese academic journals of humanities and social sciences]. Evaluation \& Management, 12(4), 28 - 32.

Zang, L. (2015). 期刊评价结果权威性影响因素分析--以人文社会科学期刊评价为 中心 [Analysis of influential factors on the authoritativeness of journal evaluation results - centered on journal evaluation of humanities and social sciences]. China Publishing Journal, 16, $13-17$.

Zhang, L., Shang, Y., Huang, Y., \& Sivertsen, G. (2021). Toward internationalization: a bibliometric analysis of the social sciences in Mainland China from 1979 to 2018. Quantitative Science Studies, 2(1), 376-408. https://doi.org/10.1162/qss_a_00102 Zhang, Y. (2015). 我国文献计量学发展的回顾与展望 [Problems, causes and treatment of academic evaluation]. Journal of Tsinghua University (Philosophy and Social Sciences), 30(6), $73-88$. 
Zhang, Y., \& Lun, H. (2019). Is Google Scholar useful for the evaluation of non English scientific journals? The case of Chinese journals. Learned Publishing, 32(2), 154 - 162. https://doi.org/https:// doi.org/10.9776/17025 


\section{Appendix}

Table A1. Disciplines classification in the CSSCI

\begin{tabular}{|l|l|l|}
\hline ID & \multicolumn{1}{|c|}{ Classification } & \multicolumn{1}{c|}{ 学科 } \\
\hline 1 & Management & 管理学 \\
\hline 2 & Marxist Theory & 马克思主义理论 \\
\hline 3 & Philosophy & 哲学 \\
\hline 4 & Religion & 宗教学 \\
\hline 5 & Linguistics & 语言学 \\
\hline 6 & Foreign Literature & 外国文学 \\
\hline 7 & Chinese Literature & 中国文学 \\
\hline 8 & Art & 艺术学 \\
\hline 9 & History & 历史学 \\
\hline 10 & Archaeology & 考古学 \\
\hline 11 & Economics & 经济学 \\
\hline 12 & Politics & 政治学 \\
\hline 13 & Law & 法学 \\
\hline 14 & Sociology & 社会学 \\
\hline 15 & Ethnology and Culture & 民族学与文化学 \\
\hline 16 & Journalism and Communication & 新闻学与传播学 \\
\hline 17 & Library, Information and Philology & 图书馆、情报与文献学 \\
\hline 18 & Education & 教育学 \\
\hline 19 & Physical Education & 体育学 \\
\hline 20 & Statistics & 统计学 \\
\hline 21 & Psychology & 心理学 \\
\hline 22 & Multidisciplinary Social Science Journals & 综合社科期刊 \\
\hline 23 & Human and Economic Geography & 人文经济地理 \\
\hline 24 & Natural Resources and Environmental Science & 自然资源与环境科学 \\
\hline 25 & Multidisciplinary University Journals & 高校综合学报 \\
\hline
\end{tabular}


Table A2. Disciplines classification in the AMI

\begin{tabular}{|c|c|c|c|c|c|}
\hline ID & $\begin{array}{c}\text { Broad Subject Categories } \\
\text { 学科大类 }\end{array}$ & Subject Categories & 一级学科 & Subject Subcategories & 二级学科 \\
\hline 1 & \multirow{10}{*}{$\begin{array}{l}\text { Humanities } \\
\text { 人文学科 }\end{array}$} & Archaeology and Museology & 考古文博 & Archaeology and Museology & 考古文博 \\
\hline 2 & & History & 历史学 & History & 历史学 \\
\hline 3 & & Marxism & 马克思主义 & Marxism & 马克思主义理论 \\
\hline 4 & & Ethnology and Culturology & 民族学与文化学 & Ethnology and Culturology & 民族学与文化学 \\
\hline 5 & & \multirow{2}{*}{ Literature } & \multirow{2}{*}{ 文学 } & Foreign Literature & 外国文学 \\
\hline 6 & & & & Chinese Literature & 中国文学 \\
\hline 7 & & Art & 艺术学 & Art & 艺术学 \\
\hline 8 & & Linguistics & 语言学 & Linguistics & 语言学 \\
\hline 9 & & Philosophy & 哲学 & Philosophy & 哲学 \\
\hline 10 & & Religion & 宗教学 & Religion & 宗教学 \\
\hline 11 & \multirow{9}{*}{$\begin{array}{l}\text { Social Sciences } \\
\text { 社会科学 }\end{array}$} & Law & 法学 & Law & 法学 \\
\hline 12 & & Management & 管理学 & Management & 管理学 \\
\hline 13 & & Environmental Science & 环境科学 & Environmental Science & 环境科学 \\
\hline 14 & & Education & 教育学 & Education & 教育学 \\
\hline 15 & & \multirow{5}{*}{ Economics } & \multirow{5}{*}{ 经济学 } & Public Finance & 财政 \\
\hline 16 & & & & Industrial Economy & 工业经济 \\
\hline 17 & & & & Finance and Banking & 金融 \\
\hline 18 & & & & Economic Management & 经济管理 \\
\hline 19 & & & & General Economics & 经济综合 \\
\hline
\end{tabular}




\begin{tabular}{|c|c|c|c|c|c|}
\hline 20 & & & & Trade Economics & 贸易经济 \\
\hline 21 & & & & Agricultural Economics & 农业经济 \\
\hline 22 & & & & International Economics & 世界经济 \\
\hline 23 & & Human Geography & 人文地理学 & Human Geography & 人文地理学 \\
\hline 24 & & Sociology & 社会学 & Sociology & 社会学 \\
\hline 25 & & Physical Education & 体育学 & Physical Education & 体育学 \\
\hline 26 & & Statistics & 统计学 & Statistics & 统计学 \\
\hline 27 & & Library, Information and Archives & 图书馆、情报与档案学 & Library, Information and Archives & 图书馆、情报与档案学 \\
\hline 28 & & Psychology & 心理学 & Psychology & 心理学 \\
\hline 29 & & Journalism and Communication & 新闻学与传播学 & Journalism and Communication & 新闻学与传播学 \\
\hline 30 & & \multirow{2}{*}{ Political Science } & \multirow{2}{*}{ 政治学 } & International Politics & 国际政治 \\
\hline 31 & & & & Chinese politics & 中国政治 \\
\hline 32 & \multirow{2}{*}{$\begin{array}{c}\text { Comprehensive Journals } \\
\text { 综合期刊 }\end{array}$} & \multirow{2}{*}{$\begin{array}{l}\text { Comprehensive Humanities and } \\
\text { Social Sciences }\end{array}$} & \multirow[b]{2}{*}{ 综合性人文社会科学 } & Multidisciplinary university journals & 高校综合性学报 \\
\hline 33 & & & & $\begin{array}{l}\text { Comprehensive Humanities and Social } \\
\text { Sciences Journals }\end{array}$ & 综合人文社科期刊 \\
\hline
\end{tabular}

